УДК 37.035:316.46:172.15

DOI:

Віталій Кульчицький, кандидат педагогічних наук, доиент кафедри педагогіки вищої школи та суспільних дисциплін ДВНЗ “Тернопільський державний медичний університет імені I. Я. Горбачевського МОЗ України”

\title{
ПАТРІОТИЗМ ЯК ФАКТОР ФОРМУВАННЯ ЛІДЕРСЬКОЇ КОМПЕТЕНТНОСТІ МОЛОДОї ЛЮДИНИ
}

У статті розкрито взаємозв'язок патріотизму з формуванням лідерських якостей особистості. Проаналізовано суть поняття "патріотизм", “лідер”, “лідерські якості", “лідерська компетентність”. Розглянуто загальні та специифічні якості притаманні особистості лідера. Зроблено висновки про те, що лідер-патріот повинен засвоїти ключові компетентності, які необхідні для особистої реалізації та розвитку, активного громадянського життя, соціальної єдності, а також володіти певною сукупністю інтелектуальних, комунікативних, організаторських та креативних якостей.

Ключові слова: патріотизм; лідер; лідерські якості; лідерська компетентність; особистість; молодь. Jim. 9.

Vitaliy Kulchytskiy, Ph.D.(Pedagogy), Associate Professor of the Pedagogy of Higher School and Social Studies Department Ternopil Ivan Horbachevskiy State Medical University Ministry of Health of Ukraine

\section{PATRIOTISM AS A FACTOR OF FORMING A LEADERSHIP COMPETENCE OF THE YOUNG PERSON}

The interrelations between patriotism with the formation of leadership attributes of the individual are revealed in the article. The essence of the concepts "patriotism", "leader", "leadership attributes" and "leadership competence" is analyzed. It is justified that patriotic upbringing is, above all, the formation of leadership attributes of an individual, the ideal of serving the people, the readiness to defend the Motherland.

It is mentioned that competence is a specially structured complex of personality attributes, which makes it possible to participate effectively in various life spheres of activity. That is why, the main four groups of leadership attributes are considered, namely: intellectual-creative; moral and strong-willed; organizational and business; emotional and communicative.

The leadership competence of young sterswasdefined as ability based on knowledge, experience and skills to organize the living space so that it would be comfortable for living and development. It is mentioned that significant potential for the formation of youth leadership competence is the involvement into the youth patriotic and nongovernmental organizations. After all, modern youth enters the world, being formed and developed as a person through different educational potential, complexity of structure, duration of functioning of the social group.

The general qualities (competence, activity, initiativity, patriotism, sociability, perseverance, self-control, efficiency, observation, independence, organization) and specific qualities (organizational insight, ability to active psychological influence, inclination to organizational work, need to take responsibility), peculiar to the personality of the leader are emphasized.

It was concluded that the leader-patriot must master key competences that are necessary for personal development and implementation, active citizenship, social cohesion and employment opportunities, as well as possess a certain setof intellectual, communicative, organizational and creative qualities.

Keywords: patriotism; a leader; leadership attributes; a leadership competence; personality; youth.

П остановка проблеми. Становлення і розвиток незалежної України, формування нових соціальнополітичних відносин можливе лише за умови усвідомлення молодим поколінням особистої відповідальності за долю своєї країни. Відтак, патріотичне виховання молоді стає важливою складовою частиною процесу формування зрілої особистості - громадянина-лідера, справжнього спадкоємця і продовжувача національних традицій 3 активною громадянською позицією.

В умовах загроз національній безпеці суспільство все більше усвідомлює гостру потребу у вихованні свідомого громадянина, фахівця, патріота. Саме тому одним із важливих напрямів діяльності навчального закладу є патріотичне виховання. Таке виховання грунтується на любові до Батьківщини, свого народу, міста, села, сім'ї, родини і $є$ потужним мотиваційним фактором, який спонукає молодь до досягнення вагомих успіхів у навчальній діяльності.

Формування громадян-патріотів України, виховання лідерів, які здатні побудувати 
громадянське суспільство, в основу якого були б закладені та постійно втілювалися демократія, толерантність та повага до прав людини, набуває сьогодні особливого значення. Саме в патріотичних почуттях відбивається ставлення

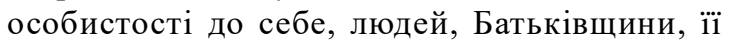
минулого, майбутнього та сьогодення. Патріотизм у сучасному розумінні - це відчуття того, що в моєму оточенні, районі, місті, країні все мене стосується, все залежить від мене.

Разом із тим, педагогічна практика свідчить, що у патріотичному вихованні існують серйозні протиріччя між потребами суспільства та можливостями освітніх закладів, сім'і, i, крім цього, недостатньо впроваджуються нові форми й методи виховної роботи, за допомогою яких формується особистість, лідер, лідерська компетентність, патріотичні почуття молодої людини.

Зміни в характері освіти для кінця XX початку XXI ст. полягають в його спрямованості, цілях, змісті, які все більш явно орієнтують його на “вільний розвиток людини”, на творчу ініціативу, самостійність молодоїлюдини, конкурентоспроможність, мобільність майбугніх фахівців. У зв' язку з цим все більш актуальним стає компетентнісний підхід у освіті, формування ключових компетенцій людини є перспективним напрямком в науці і практиці освіти. Питання про ключові компетенції є сьогодні предметом обговорення в усьому світі. Особливо актуальна ця проблема звучить зараз у зв'язку з модернізацією української освіти.

Аналіз основних досліджень і публікацій. Дослідження проблем патріотичного виховання свідчать про їх багатоаспектність. Сутність та особливості патріотизму розкриті в працях О. Воропая, В. Гонського, О. Губко, В. Іванишина, С. Килимника, А. Княжинського, Б. Непорадного, М. Пірен, П. Рогачова, Н. Свердліна, В. Сергійчука, О. Таланчука. Питання співвідношення емоційного та раціонального, загальнолюдського та національного в патріотизмі обгрунтували Я. Дзюба, О. Розумовський.

Сучасні дослідження у сфері патріотичного виховання охоплюють конкретні реалії суспільного життя в Україні. Серед досягнень педагогічної думки найзмістовнішими визначено розробки нових технологій виховання В. Андрущенка, О. Вишневського, О. Дубасенюк, М. Свтуха, І. Зязюна, В. Киричука, О. Кондратюка,П. Кононенка,В.Кременя, М. Лукашевича, Ю. Руденка, О. Сухомлинської, В. Струманського, П. Щербаня.

Серед сучасних дослідників, які працюють над питанням патріотичного виховання, лідерських та громадянських якостей особистості - I. Бех, П. Вербицька, П. Ігнатенко, С. Максименко, А. Погрібний, В. Поплужний, Ю. Руденко, К. Чорна, О. Шестопалюк та інші.

У вітчизняній науці поняття “лідерські якості”, його зміст та головні компоненти аналізуються у працях Д. Алфімова, В. Мороза, А. Куриці, Ж. Петрочко, М. Риженко, Н. Сушик, В. Ягоднікової та інших. Відповідно до їх робіт, актуальними є питання формування лідерської компетентності молодих людей.

Мета статті - проаналізувати взаємозв'язок патріотизму 3 формуванням лідерської компетентності та лідерських якостей особистості.

Виклад основного матеріалу дослідження. Розбудова Української держави ставить на порядок денний надзвичайно важливе та невідкладне завдання - виховання справжнього громадянина, патріота рідної землі. Задля консолідації суспільства необхідно, з одного боку, враховувати полікультурність українського суспільства, з іншого - посилити патріотичний характер навчання та виховання.

Важливою ланкою патріотичного становлення громадянина України є освіта, тому що вона єдиний соціальний інститут, через який проходить кожна людина, набуваючи при цьому конкретних рис особистості, фахівця та громадянина, у ракурсі нашого дослідження громадянина-лідера. Зусилля педагогів мають бути спрямовані на виховання молодих людей у дусі патріотичного обов'язку, готовності до військової служби та захисту України, повазі до національного та міжнародного законодавства, засад демократичної, правової держави.

Соціальні психологи визначають патріотизм як певне моральне ставлення й оцінку особистістю елементів Вітчизни. У конкретно історичному розгляді, з'явившись внаслідок розвитку людського суспільства, соціально-моральне, у своїй основі, патріотичне почуття набувається особистістю не через біологічну спадковість, а неодмінно під впливом соціального середовища, виховання у широкому розумінні слова.

Науковець О. Мельникова зазначає, що патріотизм є елементом як суспільної, так і індивідуальної свідомості. На рівні суспільної свідомості під патріотизмом мається на увазі національна i державна ідея єдності i неповторності цього народу, яка формується на основі традицій, стереотипів, історії і культури кожної конкретної нації. На рівні індивідуальної свідомості під патріотизмом розуміється любов до Батьківщини, гордість за свою країну, 


\section{ПАТРІОТИЗМ ЯК ФАКТОР ФОРМУВАННЯЛІЕРСЬКОӤ КОМПЕТЕНТНОСТІМОЛОДОЇ ЛЮДИНИ}

прагнення пізнати, зрозуміти й поліпшити іiі $[5,83$ $-89]$.

Таким чином, 3 точки зору сучасності, патріотичне виховання - це, у першу чергу, формування лідерської компетентності молодої людини, виховання лідерських якостей особистості, ідеалу служіння народові, готовності до захисту Батьківщини.

Сьогоднішня молодь - це завтрашні політики, економісти, викладачі та інші фахівці, які займуть провідні позиції в суспільстві, і стануть лідерами в тій або іншій сфері діяльності. Саме від їхніх дій залежатиме управління різними соціальними структурами. Відтак, правомірно стверджувати, що проблематика молодіжного середовища взагалі і лідерства зокрема є, безперечно, важливою [2, 169 - 174].

Лідерство розглядається нами не як унікальне явище, що може бути втілене шляхом домінування однієї особи над іншими, а як загальнодоступний стан максимальної творчої, професійної самореалізації людини з позицій провідного фахівця в обраній галузі. Така самореалізація буде визнаною й оціненою оточенням не за емоційними критеріями (симпатія-антипатія), а за мірою внеску людини в соціально значиму діяльність (постановка i розв'язання групового завдання). Тому розгортання лідерського потенціалу, формування лідерської компетентності може відбутись шляхом включення молоді в різні види діяльності (навчальна, наукова, трудова тощо) та соціально значимі відносини (лідерство як міжособистісна взаємодія) [8, 149 - 160].

Реформаційні процеси, започатковані на нинішньому етапі функціонування Українською державою, будуть ефективними, результативними, успішними за умови провідної ролі уїхній реалізації патріотично налаштованих лідерів-професіоналів.

Таким чином, особливим пріоритетом українського сьогодення постає формування лідерів-патріотів професіоналів своєї справи, готових і здатних свою діяльність усвідомлювати й реалізовувати як процес щоденного служіння українській громаді, країні, державі. Саме вони зобов'язані відіграти ключову роль у здійсненні реформ на місцевому рівні і стати головними ініціаторами й зацікавленими суб'єктами демократичних перетворень у країні, ефективними лідерами команд своїх співробітників.

На сучасному етапі суспільного розвитку України лідерство набуває змісту як фактор стабільності, інтеграції інтересів різних груп населення, адже лідери, формуючи стратегію й визначаючи засоби їі реалізації, виступають ініціаторами перетворень.

Аналіз досліджень XX - початку XXI ст. свідчить про одностайність учених у тому, що лідером стає найбільш ініціативна, активна й досвідчена особистість, яка цілеспрямовано прагне стати лідером. При цьому вважається, що лідер однієї групи зовсім не обов'язково стане лідером іншої групи, маючи від народження певні задатки, людина не обов'язково стає лідером, для цього їй необхідно засвоїти ключові компетентності та вміти реалізувати наявні в неї можливості [1, 3 - 14].

Так, науковець Н. Сушик, дає таке тлумачення поняття “лідер” з точки зору соціології, психології та педагогіки [9, 111 - 112]: у соціології лідер - це член групи, здатний ії̈ очолити, показати приклад, організувати виконання завдання і визнаний у цій ролі більшістю членів групи; лідер у психологічному аспекті - це: член групи, за яким вона визнає право приймати рішення в значущих для неї ситуаціях; особистість, здатна виконувати основну роль в організації спільної діяльності та регулюванні стосунків у групі; особистість, здатна впливати на окремих членів або групу загалом, спрямовувати їхні зусилля на досягнення визначеної мети; у педагогічному аспекті лідер це член колективу, який у важливих ситуаціях здатний помітно впливати на поведінку членів колективу, виявляти ініціативу в діях, брати на себе відповідальність за діяльність колективу.

Спираючись на зазначені вище поняття, можна зробити висновок, що лідер - це людина, у якої сформована лідерська компетентність, яка займає в групі авторитетне положення та спрямовує дії їі членів. Доречним є доповнення В. Войтка [6], в якому зазначено, що людина є лідером завдяки своїм особистісним якостям. Зауважимо, що компетентність - спеціально структурований комплекс якостей особистості, що дає можливість ефективно брати участь у різних життєвих сферах діяльності.

Разом 3 тим, представники сучасної психолого-педагогічної науки пропонують власне бачення властивостей особистості лідера. Так, Д. Алфімов [1] виділяє такі якості сучасної молодої людини, які характеризують їі як лідера: відповідальний, компетентний, вимогливий до себе, до людей у виконанні справи; чесний перед собою і людьми; самостійний у виконанні дорученої справи; може співчувати i співпереживати (емпатія); здатний активно впливати на інших; уміє спілкуватися та уважно слухати співрозмовника, комунікативний; організований в будь-яких сферах 


\section{ПАТРІОТИЗМ ЯК ФАКТОР ФОРМУВАННЯЛДЕРСЬКОӤ КОМПЕТЕНТНОСТІ МОЛОДОЇ ЛЮДИНИ}

життєдіяльності; уміє показати особистий приклад у поведінці і діяльності; впевнений в собі; знається у виконанні доручених справ; вміє управляти собою, володіє власними емоціями; готовий приймати відповідальні рішення.

У свою чергу, науковець Н. Семченко [7] пропонує такі групи лідерських якостей: інтелектуально-креативні (швидкість, гнучкість, аналітичність, критичність, продуктивність, точність, послідовність, ерудованість, компетентність тощо); морально-вольові (людинолюбство, патріотизм, соціальна відповідальність, порядність, чесність, оптимізм, альтруїзм, принциповість, сумлінність, самокритичність, дисциплінованість, честолюбність, упевненість у собі та своїх силах, мужність, рішучість, наполегливість тощо); організаторсько-ділові (цілеспрямованість, переконливість, організованість, діловитість, активність, енергійність, заповзятливість, дієвість, об'єктивність, справедливість, доброзичливість тощо); емоційно-комунікативні (товариськість, комунікабельність, спостережливість, емпатичність, експресивність, ініціативність, репрезентативність тощо).

Соціальний запит суспільства потребує побудови нової моделі формування патріотичної особистості з лідерськими якостями, здатної спрямувати свої сили на розвиток держави 3 розвиненою економікою, високим рівнем культури, якості життя, гуманістичних принципів. Лідером не народжуються, лідером стають, його обирає колектив за якості характеру, за вміння знайти консенсус із усіма членами колективу.

У свою чергу, патріотичне виховання молодої людини полягає у забезпеченні високого рівня освіченості й свідомості громадянина України, здатного на основі життя й досвіду власного народу та досягнень світової науки й культури, враховуючи національно-територіальні особливості України, здійснювати соціально-економічний розвиток країни, утверджуючи найважливіші ідеали гуманістичної культури й демократичних взаємин людей, відстоюючи права, гідність і честь своєї Вітчизни. Патріотичне виховання є чинником цілісного формування особистості, яке, відбиваючи систему їі поглядів, переконань, ідеалів, традицій, звичаїв, покликане формувати лідерську компетентність молодої людини [4, 55 - 62].

Практика доводить, що найбільш результативним формування лідерської компетентності молодої людини, патріотично налаштованої особистості буде за умови застосування у навально-виховному процесі інноваційних педагогічних технологій: цілеспрямованого, систематичного й послідовного впровадження в практику оригінальних, новаторських способів, прийомів педагогічних дій і засобів, що охоплюють цілісний навчально-виховний процес, а саме: інтерактивних занять, факультативних курсів, екскурсій, заходів соціального проектування, пошуководослідницької діяльності, музейної справи, молодіжного самоврядування, експериментальної роботи тощо.

Особливу увагу слід звернути на ті форми i методи виховної роботи, у рамках яких реалізується принцип суб' єкт-суб' єктних відносин учасників навчально-виховного процесу. Серед них творчі, проблемні, інтерактивні форми і методи. Вони передбачають самовираження, самореалізацію лідерського потенціалу та самоврядування молоді. Форма як зовнішнє вираження внутрішньо впорядкованих відносин вихователів і вихованців та методи як спосіб реалізації цих відносин $є$ продуктивними тоді, коли дають початок соціально-орієнтованому вектору самодіяльності особистості.

Важливо, щоб кожен навчальний заклад став для молодої людини осередком становлення громадянина-патріота України, лідера готового брати на себе відповідальність, самовіддано розбудовувати країну як суверенну, незалежну, демократичну державу, робити все для ії безпеки, сприяти єдності українського народу та громадянському миру й злагоді в суспільстві. Виходячи $з$ цього, основна ідея патріотичного виховання у навчальних закладах полягає у мотивації громадської активності молодого покоління.

Проаналізувавши сучасні підходи до лідерства, знань, умінь і навичок, якими повинен володіти лідер, нами сформульовано визначення лідерської компетентності молодої людини, а саме здатність, заснована на знаннях, досвіді, уміннях та навичках організувати свій життєвий простір так, щоб у ньому хотілося жити й розвиватися не тільки тобі, але й іншим. Лідерська компетентність - сукупність особистісних якостей молодої людини (ціннісно-смислових орієнтацій, знань, умінь, навичок, здібностей), обумовлених досвідом її діяльності в певній соціально і особистісно-значущої сфері.

Необхідно зауважити, що значний потенціал щодо формування лідерської компетентності молоді має залучення до діяльності юнацьких і молодіжних патріотичних та громадських організацій. Адже сучасна молодь входить у світ, формується й розвивається як особистість через різні за своїм виховним потенціалом, складністю структури, тривалістю функціонування колективи. I коли ми говоримо про колектив як фактор 


\section{ПАТРІОТИЗМ ЯК ФАКТОР ФОРМУВАННЯЛІДЕРСЫКОЇ КОМПЕТЕНТНОСТІ МОЛОДОЇ ЛЮДИНИ}

розвитку особистості підростаючої людини, то маємо на увазі цілу мережу колективів, до яких може входити сучасна молодь. Вони не $\epsilon$ ідентичними, і це добре. Навпаки, доцільно, щоб колективи, до яких включається особистість, були різними і за характером діяльності, і за способом входження до них молоді, і за характером ролей, які вона в цих колективах може проживати, і за терміном перебування в них [3].

Отож, проведений аналіз наукових джерел засвідчив, що в основу класифікації якостей, котрі необхідно формувати у молодих людей як майбутніх лідерів, доцільно покласти патріотизм. Саме, патріотизм як фактор формування лідерської компетентності молодої людини $є$ невід'ємною складовою цілісної особистості, спрямованої на творчу діяльність.

Висновки. Лідерські якості - це узагальнені індивідуально-особистісні та соціальнопсихологічні характеристики особистості, які дозволяють їй займати авторитетну позицію в групі, впливати на її членів, їх думки, поведінку та діяльність таким чином, щоб забезпечити їх злагоджену взаємодію та ефективну діяльність.

Саме тому, нами виділені загальні (компетентність, активність, ініціативність, патріотизм, товариськість, наполегливість, самоконтроль, працездатність, спостережливість, самостійність, організованість) та специфічні якості (організаторська проникливість, здатність до активного психологічного впливу, схильність до організаторської роботи, потреба брати відповідальність на себе, комунікабельність) притаманні особистості лідера.

Відтак, лідер-патріот повинен засвоїти ключові компетентності, які необхідні для особистої реалізації та розвитку, активного громадянського життя, соціальної єдності, а також володіти певною сукупністю інтелектуальних, комунікативних, організаторських та креативних якостей.

\section{ЛІТЕРАТУРА}

1. Алфімов Д. В. Виховання лідерських якостей школярів у сучасній загальноосвітній школі / Д. В. Алфімов // Духовність особистості: методологія, теорія і практика. - 2010. - № 4. C. 3-14.

2. Каменєва К. Л. Формування лідерських якостей в юнацькому віці / К. Л. Каменєва // Педагогічні науки: Зб. наук. пр. - Херсон: ХДУ, 2011. - Вип. 59. - С. 169-174.

3. Кутинець С. Г. Формування лідерських якостей особистості - соціальне замовлення часу. Електронний ресурс] / С. Г. Кутинець // Учительський журнал on-line. - 2016. - 7 лютого.
- Режим доступу: http://test.teacherjournal.in.ua/ index.php.

4. Мельничук Т. Виховання патріотичних, лідерських і вольових якостей - складова формування творчої особистості в університетах природоохоронного профілю / Т. Мельничук // Теорія і методика хортингу. - 2014. - Вип. 2. - С. 55-62.

5. Мельнікова О. В. Проблеми патріотичного виховання сучасної молоді / О.В.Мельнікова // Духовність особистості: методологія, теорія і практика. - 2012. - Вип. 2. - С. 83-89.

6. Психологический словарь / Под редакцией В. И. Войтко (на украинском языке). - К.: Главное издательство издательского объединения “Вища школа", 1982. - 218 с.

7. Семченко Н. О. Педагогічні умови формування лідерських якостей майбутніх учителів у позааудиторній діяльності: дис. канд. пед. наук: 13.00.04 / Н. О. Семченко. - Харків, 2004. -215 c.

8. Сопівник Р. В. Формування лідерських якостей майбутніх фахівців агропромислової галузі / Р. В. Сопівник // Духовність особистості: методологія, теорія і практика. - 2015. - Вип. 4. - C. 149-160.

9. Сушик Н. Теоретичні основи формування лідерських якостей учнівської молоді / Н. Сушик // Науковий вісник Східноєвропейського національного університету імені Лесі Українки. - Луцьк, 2013. - С. 110-115.

\section{REFERENCES}

1. Alfimov, D. V. (2010). Vykhovannia liderskykhy akosteis hkoliariv u suchasnii zahalnoosvitnii shkoli [Formation ofleadership attributes of pupils in modern general education school]. Spirituality of the person: methods, theory and practice, 4, pp. 314. [in Ukrainian].

2. Kamenieva, K. L. (2011). Formuvannia liderskykhy akostei v yunatskomu vitsi [Formation of leadership attributes in teenage]. Educational studies. Collection of research papers. Kherson: KhDU, 59, pp. 169-174. [in Ukrainian].

3. Kutynets, S. H. (2016). Formuvannia liderskykhy akostei osobystosti - sotsialne zamovlennia chasu [Formation of leadership attributes of personality - the social mandate of nowadays]. Teachers' journal online, Feb $7^{\text {th }}$.Access mode: http:/ /test.teacherjournal.in.ua/index.php [in Ukrainian].

4. Melnychuk, T. (2014). Vykhovannia patriotychnykh, liderskykh i volovykhy akostei - skladova formuvannia tvorchoi osobystosti v universytetakh pryrodookhoronnoho profiliu [Formation of patriotic, leadership and volitational attributes as an element of formation of creative personality in nature-oriented 
universities].Khortyng theory and methods, 2, pp. 55-62. [in Ukrainian].

5. Melnikova, O. V. (2012). Problemy patriotychnoho vykhovannia suchasnoi molodi [Issues of patriotic education of modern youth]. Spirituality of the person: methods, theory and practice, 2, pp. 83-89. [in Ukrainian.

6. Voytko, V. I. (Ed.) (1982). Psikhologicheskiy slovar [Psychological glossary]. Kyiv:Main publishing house of publishing unity "Vyshcha shkola", 218 p. [in Ukrainian.

7. Semchenko, N. O. (2004). Pedahohichni umovy formuvannia liderskykhy akostei maibutnikh uchyteliv u pozaaudytornii diialnosti [Pedagogical conditions of formation of leadership attributes of future teachers during extracurricular activities]. Candidate's thesis. Kharkiv, 215 p. [in Ukrainian].

8. Sopivnyk, R. V. (2015). Formuvannia liderskykhy akostei maibutnikh fakhivtsiv ahropromyslovoi haluzi [Formation of leadership attributes of future specialist in agriculture]. Spirituality of the person: methods, theory and practice, 4, pp. 149-160. [in Ukrainian].

9. Sushyk, N. (2013). Teoretychni osnovy formuvannia liderskykhy akostei uchnivskoi molodi [Theoretical basis of formation of pupils' leadership attributes]. Bulletin of Lesya Ukrainka Eastern European National University. Lutsk, pp. 110-115. [in Ukrainian].

Стаття надійшла до редакції 30.07.2018

УДК 793.31

DOI:

Петро Фриз, кандидат мистеитвознавства, доиент кафедри культурології та мистеиьккої освіти Дрогобицького державного педагогічного університету імені Івана Франка

\section{УКРАЇНСЬКІ ХОРЕОГРАФІЧНІ ТРАДИЦІЇ ЯК ВІДОБРАЖЕННЯ СОЩІОКУЛТУРНОГО ДОСВІДУ}

У статті розвинуто концептуальний підхід до аналізу украйнських хореографічних традицій, в основу якого покладено розуміння хореографічної творчості як осмислення буття через картину внутрішнього світу людини. Проаналізовано культуротворчу функиію українського таниювального мистецтва, актуалізацію фольклорних канонів, оновлення народних традицій та їх включення у сучасну хореографічну культуру.

Така феноменологічна спеиифікаиія хореографічного мистеитва як мистеитва наскрізь умовного $i$ опосередкованого виявляється у принщипі єдності виконання і виховання, визначаючи значення танцю як вихідної умови існування.

Ключові слова: танець; хореографічне мистеитво; хореографічна традиція; українська народносиенічна хореографія; народна танцювальна творчість; соиіокультурний досвід.

Jim. 6.

Petro Fryz, Ph.D.(Study of Art), Associate Professor of the Cultural Studies and Artistic Education Department Drohobych Ivan Franko State Pedagogical University

\section{UKRAINIAN CHOREOGRAPHIC TRADITIONS AS REFLECTION OF THE CULTURAL AND SOCIAL EXPERIENCE}

The new conceptual approach to the researches of the Ukrainian choreographic traditions has been developed in the article. This approach is based upon the phenomenological comprehension as the particular contemplation of the existence within one's personal inner world. The ? ultural function of Ukrainian dancing art, actualization of folk canons, updating of folk traditions in a modern choreographic culture are analysed. Folk dance is the transmitter of cultural code of people, incarnates the important lines of national culture, is the repeater of the system of values (public traditions, norms, standards, ideals and others). With the aid of the mediation of the means of this inner world's revelation choreographic traditions comes to existence as a specific system of choreographic conventions where the general paradox of performance is displayed, namely that of the productivity of reproduction and retrospection. Reflection and mediation explain the paradoxical stability and productivity of this canon as well as that of the minimalistic selfrestriction coming to the extreme conditions of an artistic experiment. A particular actuality of the choreographic space and time has been stressed. Such phenomenological specification of choreographic art as the conventional and mediated art mainly finds its revelation in the principle of the unity of performance and instruction. The traditions, tendency and law of figurative-semantic transformation of the traditional 